NASA Technical Memorandum 102105

\title{
Space Station Freedom Solar Array Design Development
}

Cindy Winslow and Kevin Bilger

Lockheed Missiles \& Space Co., Inc.

Sunnyvale, California

and

Cosmo R. Baraona

Lewis Research Center

Cleveland, Ohio

Prepared for the

24th Intersociety Energy Conversion Engineering Conference

cosponsored by the IEEE, AIAA. ANS, ASME, SAE, ACS, and AIChE Washington. D.C. August 6-11, 1989

\section{N/SA}




\section{SPACE STATION FREEDOM SOLAR ARRAY DESIGN DEVELOPMENT}

Cindy Winslow and Kevin Bilger

Lockheed Missiles \& Space Co., Inc.

P.O. Box 3504

Sunnyvale, California 94088-3504

and

Cosmo R. Baraona

National Aeronautics and Space Administration

Lewis Research Center

Cleveland, Ohio 44135-3191

\section{ABSTRACT}

The Space Station Freedom Solar Array Program is required to provide a $75 \mathrm{~kW}$ power module that uses eight solar array (SA) wings over a four-year period in low Earth orbit (LEO). Each wing will be capable of providing $23.4 \mathrm{~kW}$ at the 4-year design point. LMSC is providing the flexible substrate $S A s$ that must survive exposure to the space environment, including atomic oxygen, for an operating life of fifteen years. Trade studies and development testing, important for evolving any design to maturity, are presently underway at Lockheed Missiles \& Space Company, Inc. (LMSC) on the flexible solar array. The trade study and development areas being investigated include solar cell module size, solar cell weld pads, panel stiffener frames, materials inherently resistant to atomic oxygen, and weight reduction design altematives.

\section{INTRODUCTION}

Producibility and ease of replacement of damaged portions of the approximately $14.2 \mathrm{ft}$ long SA panel during fabrication are the primary reasons for investigation of solar cell module size and dual n-type solar cell weld pad designs. Design optimization in both of these areas will reduce the labor hours associated with fabrication and rework (replacing broken solar cells) of the SA panels. Stiffener frame selection will be based on a cost/weight analysis. Candidate materials that are inherently resistant to atomic oxygen are being investigated as a backup to the baseline thin-film $\mathrm{SiO}_{2}$ protection for the Kapton(8) substrate.

Alternative designs considerations to reduce SA wing weight include thinner solar cells, changing containment box and mast canister material from aluminum to graphite epoxy, using motors specifically designed for each task, and a combination of containment box and cradle latching mechanisms for launch and assembly.

The development test program will support the preliminary and final designs. Several subcontractors will support the above effort in the development of the designs for the solar cell assembly, the bypass diode, the Kapton film coated for $A O$ protection, the coilable longeron wing extension mast canister, the motor drive assembly (MDA), and the flat collector circuit. The test program emphasizes support for those aspects of the array wing design that are different from the SAFE array and other LMSC flexible SA programs. The test program will also aid in providing confidence that the fifteen-year array operating life requirement in LEO can be met. This paper briefly summarizes the array baseline design and describes the trade studies and development testing currently underway at LMSC.

\section{DESIGN REQUIREMENTS}

The major design requirements are shown in Figure 1. The fifteen-year on orbit operation life requirement and the large size of the SSF array wings present the major design challenges. Several other challenges are depicted in Figure 2.

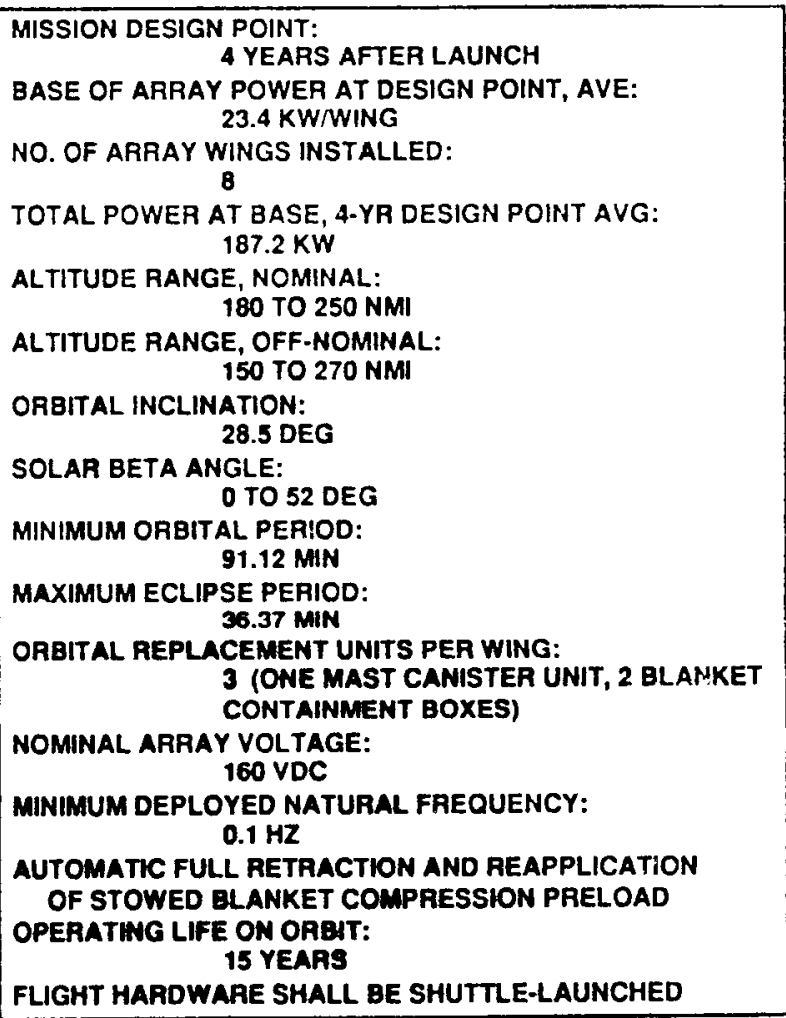

Fig. 1 Space Station Array Design Requirements

\section{BASELINE DESIGN}

In the early 1970 s basic design decisions were made on how to best approach the design of solar arrays capable of producing hundreds of kilowatts. Low weight, low launch volume, adequate deployed structural stiffness, fifteen-year temperature cycle life for the extended array, and adaptability of low-cost automated assembly were the key considerations. Current 


ATOMIC OXYGEN PAOTECTION DISIGN DEVELOPMENT
FOR KAPTON AND MAST
- PLASMA INTERACTION EFFECTS
- THERMAL CYCLE LONG-LIFE SURVIVABILITY OF CELL
BONDS
CONTAMINATION OF ARRAYS BY SPACE STATION
- LARGE AREA CELL LAUNCH PACKAGING DESIGN
- LOW PRODUCTION COST DESIGN
PERRER FO COMMONALITY DEFINED FOR BEST
- CRU ASTRONAUTIMSC INTERFACE DESIGN
GROUND EXTENSION TEST OF TWO BLANKET ARRAY
PRODUCTION COST REDUCTION

Fig. 2 Space Station Freedom Technical and Program Challenges

designs reflect mature technology that has been developed and demonstrated while the basic concept remains unchanged. The technology used on the Space Station Freedom Solar Array (SSFSA) design is based largely on the Solar Array Flight Experiment (SAFE), while taking advantage of advances in large area solar cell design and adding protection for the array from the LEO atomic oxygen (AO) environment.

The SSFSA will support a $75 \mathrm{~kW}$ bus with eight array wings cver a four-year period in l-EO. The SSFSA is $33.8 \mathrm{ft}$ by $113.7 \mathrm{ft}$ when fully deployed; the mast canister is 32 inches in diameter and $9 \mathrm{ft}$ tall. The current veight is $1650 \mathrm{lb}$. The f'exible substrate array must survive the space environment for iifteen years. This includes AO expusure and 87,000 thermal cycles. The baseline AO protection is based on the results of the Photovoltaic Array Environmental Protection (PAEP) Program ${ }^{1}$ being performed by LMSC for NASA-LeRC. In addition to the SSFSA, two free-flying Platforms will use smaller array wings with maximum hardware commonality to reduce program cost.

The baseline SSF exterded array configuration is shown in Figure 3. Figure 4 illustrates the panel elements. The mechanical design consists of two blanket boxes made of aluminum honeycomb panels, shown in Figure 5. Motor drive assemblies release the latches and relatch when required. The blanket tension and guiclewire mechanisms are housed in the underside of the containment box, and three tensioned guidewires per blanket control the location of the blankets during extension and retraction. The tension mechanism applies $75 \mathrm{lbs}$ of tension to each blanket.

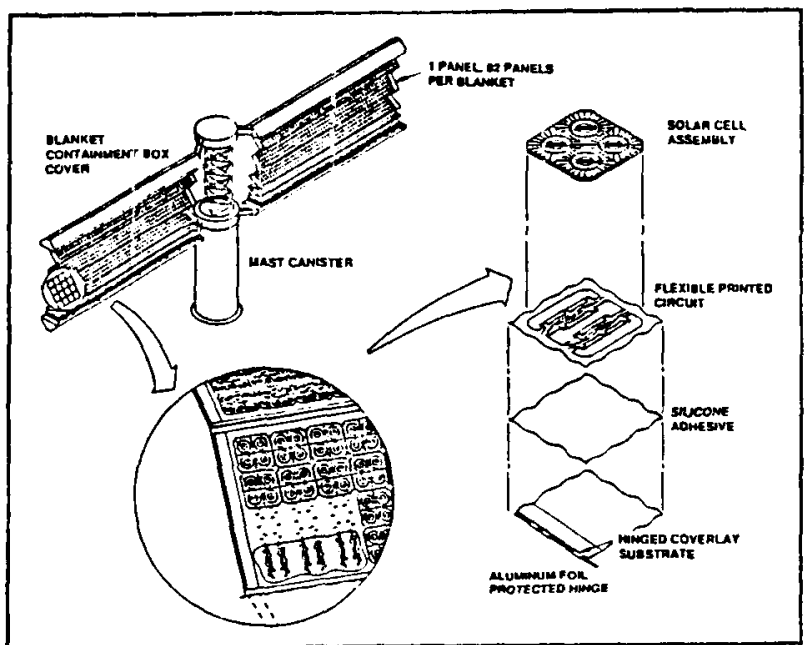

Fig. 4 Space Station Freedom Panel

The positioning mechanism places the arrays in the ready-toextend configuration, and returns them to the launch configuration. The mast draws out the blankets that are attached to the unlatched box covers ard pulls the blanket

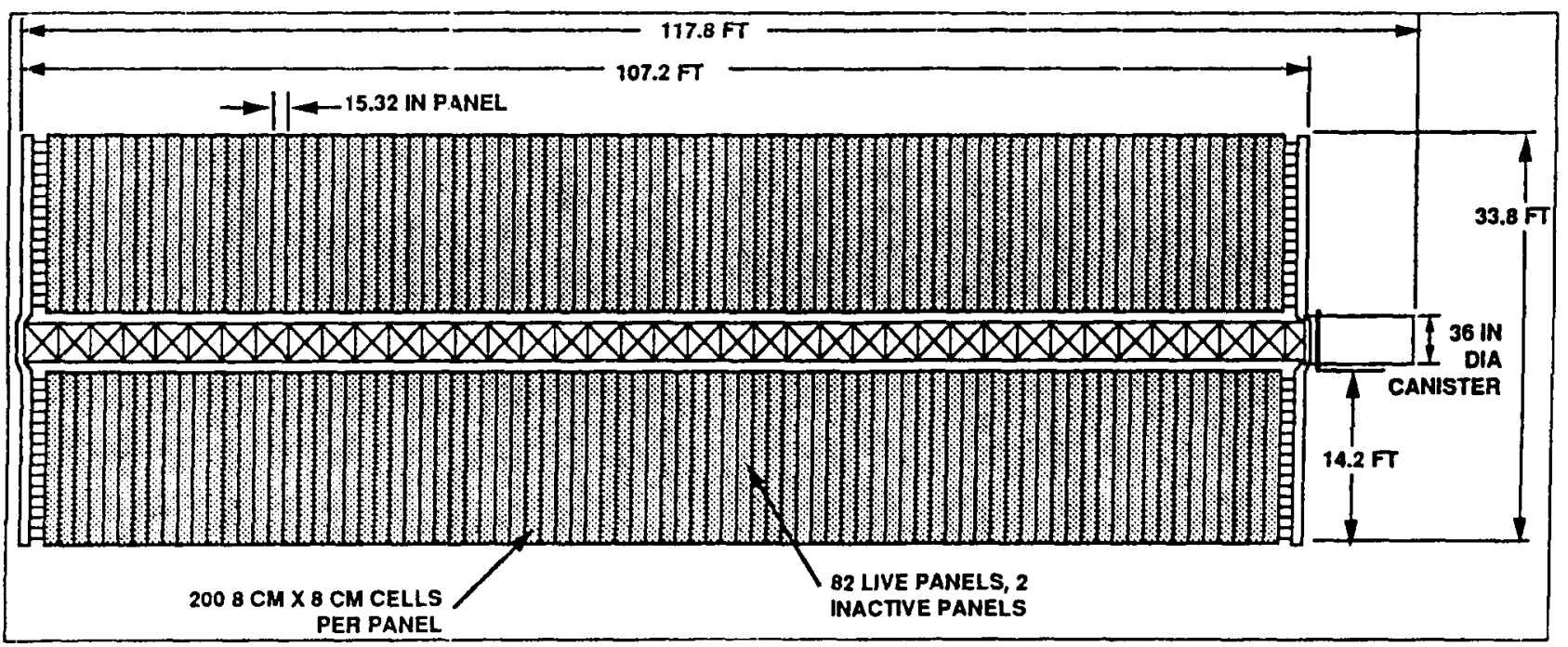

Fig. 3 Space Station Freedom Solar Array Deployed Configuration 


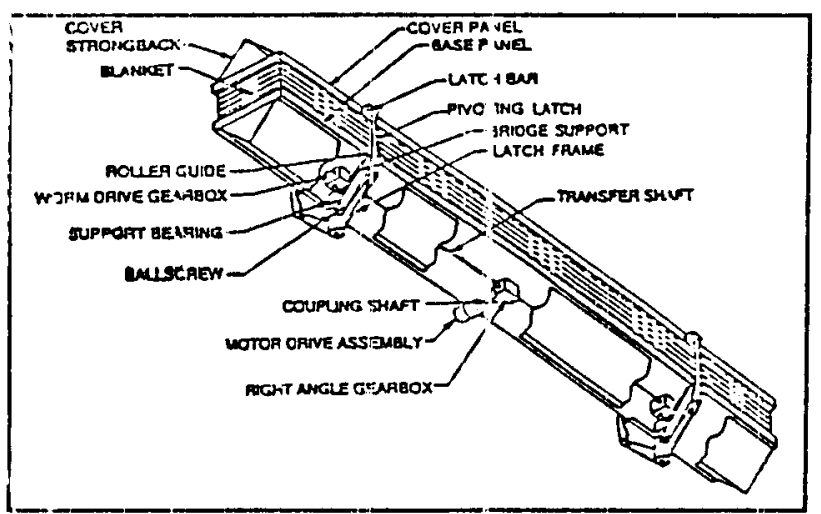

fig. 5 Space Station Freedorn Contairment Box Isometric Drawing

tension mechanism out of the box. The mast stiffness and blanket tension mechanism control extended wing natural fiequency.

Each blanket contains 82 live panels and two dummy panels. The Kapton coverlays are held together with 0.030 in. diameter hinge pins through a $14.2 \mathrm{ft}$. piano hinge, and stiffener frames on each panel assure proper zero gravity fold-up, while steel leaf springs are attached to the frames at the panel hinge lines to assure retraction memory of the blanket. The cells are largearea wrap-through silicon cells $8 \mathrm{~cm} \times 8 \mathrm{~cm} \times 200 \mu \mathrm{m}(0.008$ in.) protected by 0.005 in. $\mathrm{CMX}$ cover glass. Parallel gap welding is used to bond cells to the printed copper interconnect. Approximately 400 series connected solar cells provide 160 Vdc nominally at four years. An electrical circuit is comprised of two series connected SA panels. Each panel is therefore one half circuit and is 15.3 in $\times 14.2 \mathrm{ft}$.

\section{TRADE STUDIES}

The large size of the SSFSA panels makes them difficult to manufacture as one unit. If rework were required on a panel, 200 solar cells would be tied up until disposition. Trade studies are underway to select an effective module size for fabrication. Our baseline is a 100 cell half panel, with the copper circuitry brazed in the center. The PAEP panels were made in 40 cell modules. This size is considerably easier to handle. An eight-cell module is also being investigated that would tie up the smallest number of cells in case repair were necessary, but would significantly increase the number of piece parts.

The baseline SSF solar cell has ten weld pads used for electrical connection with external circuits. A dual weld pad design is proposed for the SSF solar cell to simplify repairs in manufacturing SAs. The dual-pad design builds redundancy into the cell, making reweld possible and cell replacement less skill-dependent. Baseline repair methods, statistical data, and repair rate analysis were obtained from other programs. Single weldpad solar cells allow one weld per cell per assembly. However, if redundancy is built into the cell and the flexible circuit, a rework can be made based on the failure mode. Possible failure modes include poor contacts due to bad weld joints, cracked or broken cells in a module assembly, and cracked cells in a panel assembly.

The stiffener frame provides rigidity to the panel to aid in retraction of the arrays. The baseline material, beryllium, is currently being traded off against graphite/epoxy and a graphite/thermuplastic. Beryllium is stable in the $A O$ environrnent. Tiree major concems are: (1) handling ( $B e$ has low impact resistance and is notch sensitive), (2) safety (Be is toxic), and (3) lack of flight history of Be in this application. Graphite thermoplastic is possibly stronger in the transverse direction than $\mathrm{Gr} / \mathrm{E}$, pernitting the use of a unidirectional ply for construction. However, this composite would need to be protected against $A O$, has no flight or manufacturing history, and would provide reduced stiffness across the cross-braced joint region.

Kapton with $130 \mathrm{O} \AA$ of $\mathrm{SiO}_{2}$ sputter-coated on both sides is the baseline $S A$ panel substrate. It is transparent, flexible, $A O$ resistant, and survives processing and handling for flexible printed circuitr fabrication. The potertial formation of pin holes ard the low flexibility of the material are concerns; therefore, alternate materials are being studied under the PAEP contract. These include: (1) DuPont 92-1, a proprietary material: (2) KJ-36, a multilayer with siloxypolyimide clad to Kapton-both siles: (3) Kapton F, a multilayer laminate of FEP/Kapton/FEP; and (4) K/T/K, a laminate of Kapton/FEP/Kapton. Characteristics are provided in Figure 6.

\begin{tabular}{|c|c|c|c|c|}
\hline $\begin{array}{l}\text { MATEAIAL } \\
\text { (2 MIL) }\end{array}$ & $\begin{array}{l}\text { FLIJAT } \\
\text { EXPEPIENCE }\end{array}$ & $\begin{array}{l}\text { EXPECTED AOO } \\
\text { SURVIVABILITY }\end{array}$ & AVAILABILITY & $\begin{array}{l}\text { MANUFACTUA. } \\
\text { ABIL ITY }\end{array}$ \\
\hline KAPTON & $\begin{array}{l}\text { SAFE. GEO. } \\
\text { NSTS. }\end{array}$ & $0.3 \mathrm{YA}$ & COMMEACIAL & NO PROBLEM \\
\hline $\begin{array}{l}\text { SIO } \\
\text { COATED } \\
\text { KAPTON }\end{array}$ & NSTS 15 YA & NEW & $\begin{array}{l}\text { DELICATE } \\
\text { PROCESS }\end{array}$ & \\
\hline $92-1$ & NONE & $15 \mathrm{YA}$ & $\begin{array}{l}\text { NEW } \\
\text { PROCESS }\end{array}$ & NO PAOBLEM \\
\hline$K \sqrt{k-36}$ & MONE & $15 \overline{Y A}$ & $\begin{array}{l}\text { NO PILOT RUN } \\
\text { DIFFICULT }\end{array}$ & NO PHOQLEM \\
\hline KAPTON F & $\begin{array}{l}\text { NSTS, } \\
\text { SOLAR MAX }\end{array}$ & $\begin{array}{l}\text { NSTS: } 15 \text { YA } \\
\text { S. MAX: }<5 \text { YA }\end{array}$ & COMMERCIAL & BONDABILITY \\
\hline $\begin{array}{l}\text { KAPTON } \\
\text { KITIK } / \mathrm{SIO}_{2} \\
\text { COATED }\end{array}$ & NONE & 15 YA & $\begin{array}{l}\text { OIFFICULT, } \\
\text { CREASES }\end{array}$ & $\begin{array}{l}\text { OULKY, } \\
\text { EFFECTS OF } \\
\text { CREASES }\end{array}$ \\
\hline
\end{tabular}

Fig. 6 Comparison of Kapton Substrates

Currently, weight reduction possibilities are being considered in seven areas of the SA wing design. Reducing the thickness of the baseline solar cell from 0.008 in. to 0.004 in or 0.002 in could save $52-78$ lbs per wing assembly, but will require resizing of the $S A$ based on the reduced thin cell current output. Changing the material of the containment box and the mast canister from aluminum to graphite epoxy could save $8 \mathrm{lbs}$ and $13 \mathrm{lbs}$ respectively. Common MDAs are less costly, but $28 \mathrm{lbs}$ could be saved if there were unique MDA designs for latching, positioning, and extension. If the deployment time required were greater than 15 minutes, the extension motor would weigh less. The positioning mechanism mass could be lowered 30 lbs with manual positioning and $15 \mathrm{lbs}$ with one short positioning out and in. Combining the containment box and launch cradle latching mechanisms could save $100 \mathrm{lbs}$ on the wing, but only 25 lbs for the complete system.

\section{DEVELOPMENT TEST PLAN}

Proof of concept, thanufacturability, and lower overall program risk are among the reasons for performing development testing on hardware. Early identification of tooling and manufacturing needs allows time to design and fabricate necessary tools; develop and plan effective manufacturing processes; integrate facilities, tooling and materials; and develop necessary skills.

The planned blanket, box, and wing component-level testing and the wing assiembly evaluation testing are depicted in Figure 


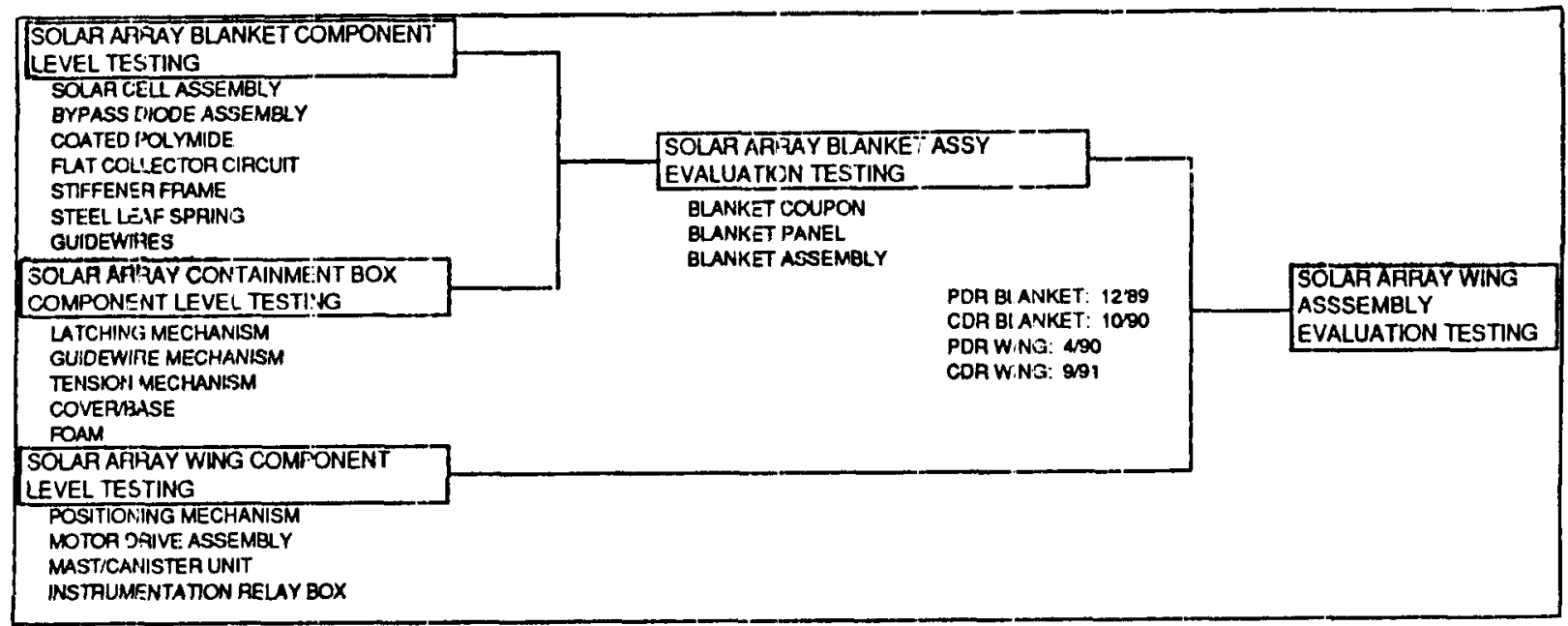

Fig. 7 Space Station Freadom Development Test Flow

7. The blanket components such as the solar cells, bypass diodes, coated Kapton, and flat collector circuit, undergo many development tests at the vendors subcontracted to LMSC. The solar cells and diodes will undergo weld development at LMSC. The reverse breakdown characteristics of the cell will be tested at LMSC, and verification of bypass diode operation with module shadowing will also take place.

The containment box latching/preload, guidewire, and tension mechanisms all undergo functional and environmental testing. The structural properties of the box cover and base are evaluated, and the preload foam will be subjected to creep, compression, and environmental testing. The blanket/box assembly testing is shown in Figure 8.

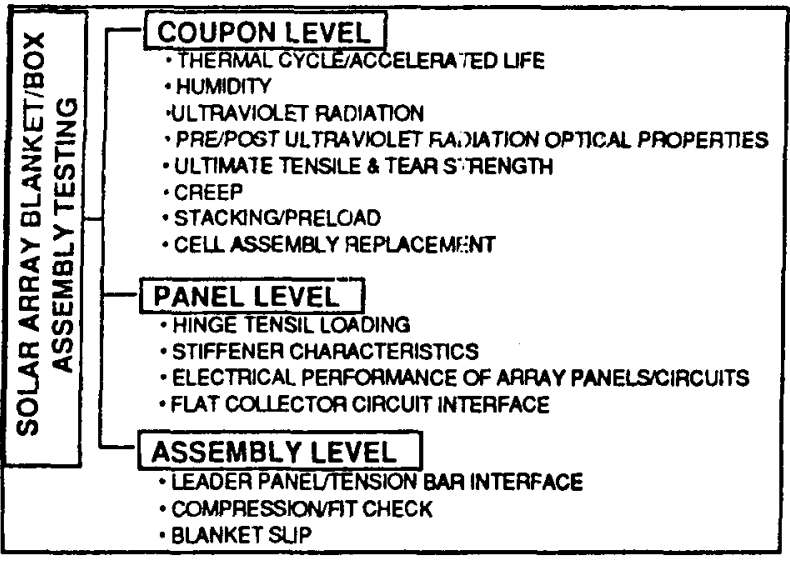

Fig. 8 Space Station Freedom Solar Array Blanket/Box Assembly Testing

To evaluate the SA wing, stowed-alignment fit checks, deployment, stowage, functional, acoustic, and first-motion thermalvacuum tests will be performed. Four tests are included in the deployment/stowage fit checks: (1) distance and duration, (2) tension mechanism verification, (3) guidewire mechanism verification, and (4) latching/preload mechanism verification.

\section{CONCLUDING REMARKS}

Currenty, five 40-cell modules electrically connected per panel appears advantageous. The modules are of manageable size and do not tie up too many cells in case a repair is necessary, yet there is not an unwieldy amount of piece parts. Our circuirty has been designed to incorporate the twenty weld pads (ten double weld pads) now on the solar cell. Labor hours required for rework will decrease with this incorporation. Stiffener frame selection will be based on a cost/weight analysis. As a backup to the baseline thin-film $\mathrm{SiO}_{2}$ protection for the Kapton substrate SA panels, several candidate materials that are resistant to atomic oxygen are being investigated .

Design changes to reduce the overall SA wing weight have been studied. These include a combination of containment box and cradle latching mechanisms for launch, thinner solar cells, changing containment box and mast-canister material from aluminum to graphite epoxy, and using motors specifically designed for each task. The development test program will provide confidence that the fifteen-year array operating life requirernent in LEO can be met while emphasizing those aspects of the array wing design that are different from the SAFE array and from other LMSC flexible SA programs.

\section{ACKNOWLEDGEMENTS}

The effort reported on in this paper is being performed under contract to the Rocketdyne Division of Rockwell International as a part of the NAS3-25082, NASA Lewis Research Center Space Station, Work Package-04, Electrical Power System Phase C/D program. The authors gratefully acknowledge the dedicated efforts of Abida Hashmi, responsible solar cell engineer, for pursuing various repair methods leading to the dual weld pad design; of Ann Marie Morris, mass properties engineer, for repeatably analyzing different design options; and of Ken Miyagi and George Welik for their advice and assistance. 


\section{REFIERENCES}

1. Bilger, Kevin M., Helen B. Gjerde, and B. L. Sater,

"Photovoltaic Anay Envirorimental Protection Program", 24th

Intersociety Energy Conversion Engineering Conference, 6-11

August 1989.

2. Solar Array Technology Development for SEP - Final

Report, LMSC-D17820, 9 January 1981.

(B) Dupont Registered Trademark 


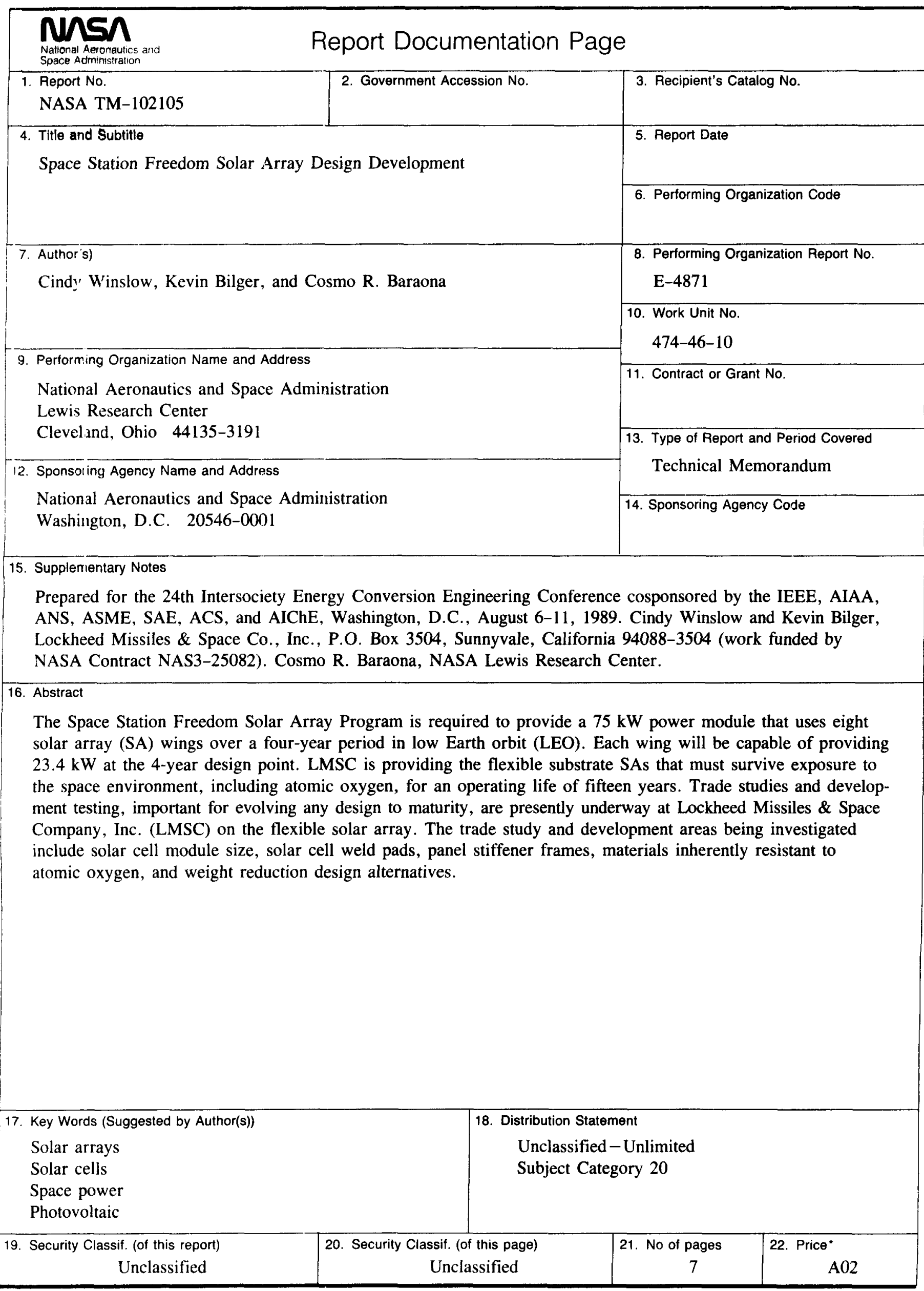

